\title{
PENGARUH KUALITAS PELAYANAN TERHADAP KEPUASAN PELANGGAN DALAM MEMBENTUKLOYALITAS PELANGGAN PADA CLINICNATASHASKIN CAREMEDAN
}

\author{
Mariyanti Sirait $^{1}$, Abd. Rasyid Syamsuri ${ }^{2}$ \\ ${ }^{1}$ Alumni Sarjana Ekonomi Universitas Sumatera Utara \\ ${ }^{2}$ Dosen Sekolah Tinggi Ilmu Ekonomi (STIE) Labuhanbatu
}

\begin{abstract}
This research aims to determine the effect of service quality for customer satisfaction in forming customer loyalty in Clinic Natasha Skin Care Medan.This type of research is quantitativeresearch. The sampling technique using incidental sampling method.The type of data used are primary data and secondary data.Data analysis techniques used in this research is descriptive analysis, multipleanalysisregression, hypothesis testing using simultaneous significant test (test F), significant testing partially (ttest), and testing the coefficient of determination $\left(R^{2}\right)$. These results indicating that together for a positiveand significantinfluence between service qualityfor customer satisfaction in forming customer loyalty in Clinic Natasha Skin Care Medan. The partial test ( $t$ test) note that variables and service service quality for customer satisfaction in forming customer loyalty in Clinic Natasha Skin Care Medan. While the variablecustomer satisfaction no effect dan significant impact on the purchase decisionat Clinic Natasha Skin CareMedan. Through testing ajusted adjusted coefficient of determinationR Square of 0.528 means that $52.8 \%$ factors service quality and customer satisfactioncan be explained by other factors which arent pursuing by other researcherpact and significantly to customer loyalty.
\end{abstract}

\section{Keywords: Service Quality, Satisfaction, Customer Loyalty.}

\section{PENDAHULUAN}

Perkembangan industri kecantikan saat ini sangat pesat, penampilan merupakan hal yang sangat penting bagi sebahagian orang. Penampilan yang baik dan menarik ditunjang dari berbagai macam hal diantaranya adalah bagaimana fashion serta cara merawat tubuh. Dalam hal perawatan tubuh, kesehatan kulit dan tubuh merupakan fokus utama yang biasanya selalu diperhatikan. Dengan memiliki kulit yang sehat, maka akan terlihat lebih cantik dan menarik.Kebutuhan wanita terhadap fasilitas kecantikan sekarang ini terus meningkat, karena wanita sudah menyadari begitu pentingnya kesehatan tubuh dan merawatnya agar terlihat cantik dan sehat. Banyak tempat yang menawarkan perawatan kecantikan, mulai dari salon-salon kecil hingga klinik-klinik kecantikan mewah. Semuanya memiliki kelebihan dan kekurangan masing-masing.

Konsumen juga menjadi semakin selektif dalam memilih tempat perawatan kecantikan mana yang paling sesuai dengan kebutuhan mereka sehingga bisnis ini pun menjadi semakin kompetitif.Hal inilah yang membuat bisnis kecantikan kulit semakin banyaknya bermunculan. Klinik-klinik kecantikan yang menawarkan berbagai jenis perawatan dan berbagai jenis teknologi terbaru mengakibatkan semakin meningkatnya tuntutan masyarakat terhadap kualitas pelayanan perawatan kecantikan itu sendiri. Kualitas layanan yang baik akan membuat pelanggan merasa puas. Kepuasan pelanggan ditentukan oleh kualitas produk dan 
layanan yang dikehendaki pelanggan, sehingga jaminan kualitas menjadi kualitas utama bagi suatu perusahaan.

Kepuasan pelanggan harus disertai dengan loyalitas pelanggan, kepuasan harus menyangkut apa yang diungkapakan oleh pelanggan tentang presepsi dan harapannya kepada layananan klinik kecantikan yang diperoleh. Sedangkan loyalitas berkaitan dengan apa yang dilakukan oleh pelanggan setelah berinteraksi dalam suatu proses layanan dari klinik kecantikan tersebut. Pelanggan yang loyal cenderung kembali menggunakan jasa klinik kecantikan yang menurut mereka dapat memberikan kepuasan. Hal ini menyiaratkan bahwa kepuasan pelanggan tidaklah cukup, karena puas atau tidak puas hanyalah salah satu bentuk emosi. Disamping itu loyalitas pelanggan juga tidak kalah relevannya untuk dianalisis sebab sikap loyal pelanggan akan timbul setelah pelanggan merasa puas atau tidak puas terhadap layanan yang diterimanya. Banyak perusahaan yang semakin yakin bahwa pemasaran dengan konsep mempertahankan pelanggan sangatlah menguntungkan karena itulah loyalitas menjadi hal yang patut dipertahankan oleh perusahaan.

Natasha Skin Care adalah salah satu pusat kecantikan yang beralamat di jalan Kaliurang Km.5 No.53 Depok, Sleman, Yogyakarta ini, kini telah memiliki 37 cabang di 23 kota di Indonesia salah satunya di Sumatera Utara/Medan. Komitmen Clinic Natasha Skin Care adalah memberikan pelayanan nomor satu di tangan para profesional yang handal. Natasha Skin Care melakukan berbagai macam terobosan seperti menggunakan peralatan atau mesinmesin yang canggih dan berteknologi modern yang belum digunakan pusat perawatan kecantikan lainnya. Hal itu juga didukung dengan misinya yakni "Lebih Aman Dengan Sterilisasi".Klinik kecantikan Natasha Skin Care selalu mengikuti dan menggunakan alat-alat baru dan senantiasa memberikan tambahan ilmu pengetahuan baru kepada dokter-dokter, sehingga dapat dijadikan patokan kenyamanan dalam merawat kulit. Hal ini sangat penting diketahui agar dapat memperkirakan kebutuhan konsumen pada masa sekarang dan akan datang yang berdampak pada keinginan membeli dari para konsumen. Dengan semakin banyaknya klinik kecantikan menyebabkan semakin banyak pula pelayanan yang ditawarkan kepada konsumen, hal ini akan memberikan kesempatan kepada konsumen untuk dapat memilih dan membeli produk yang sesuai dengan keinginan dan kebutuhan konsumen.

Natasha Skin Care juga membangun citranya melalui segmen atau sasaran konsumen yang dituju sebagai pusat perawatan kecantikan untuk kalangan wanita modern yang tinggal di perkotaan. Hal itu ditunjukkan dari segmen pasar yang dibidik Natasha Skin Care yakni memberikan berbagai jenis pelayanan kepada masyarakat khususnya kaum wanita dalam rangka menjawab gaya hidup kaum wanita di perkotaan yang selalu menuntutnya untuk lebih memperhatikan penampilan. Tidak hanya dalam berbusana, namun juga penampilan kulit wajah dan tubuh. Artinya, penampilan diri seutuhnya (total look) menjadi sebuah kebutuhan penting untuk menunjang kepercayaan diri khususnya bagi seorang wanita.

Natasha Skin Care yang mencitrakan diri sebagai pusat perawatan kecantikan bagi wanita modern, ditunjukkan dengan kartu pelanggannya yang diberi nama Executive Card dan Student CardExecutive diberikan kepada pelanggan umum seperti wanita karir yang umumnya mementingkan penampilan di tempat kerja. Selain wanita karir atau wanita bekerja, kartu ini juga berlaku bagi ibu-ibu rumah tangga yang tinggal di perkotaan dan selalu memperhatikan penampilan fisik. Namun dalam perkembangannya, pemegang kartu ini juga banyak dari kalangan laki-laki yang tinggal diperkotaan yang juga mementingkan penampilan. Sementara Student Card diberikan kepada pelanggan yang masih berstatus sebagai pelajar dan mahasiswa. Fasilitas yang diberikan kepada pemegang kartu ini adalah berupa diskon 
sebesar $20 \%$ untuk perawatan dan $10 \%$ untuk cream. Dilihat dari segmen sasaran Natasha Skin Care yakni wanita modern khususnya yang tinggal di perkotaan, dapat dikatakan bahwa Natasha Skin Care ingin membangun citra di mata pelanggan akan pentingnya perawatan tubuh.

Tabel Jumlah Pengguna Skin Care Kota MedanTahun 2014

\begin{tabular}{|c|l|c|}
\hline Tahun & \multicolumn{1}{|c|}{ Nama Skin Care } & $\begin{array}{c}\text { Jumlah } \\
\text { (Pengguna) }\end{array}$ \\
\hline 2014 & Natasha Skin Care Medan & 29000 Orang \\
\hline 2014 & Erha Clinic & 27500 Orang \\
\hline 2014 & London Beauty Center (LBC) & 15000 Orang \\
\hline 2014 & Klinik Dermatologi - Medan & 1275 Orang \\
\hline 2014 & Slimline - Medan & 713 Orang \\
\hline 2014 & Iki Skin Care - Medan & 625 ORang \\
\hline 2014 & Ricca Skin Care - Medan & 552 Orang \\
\hline 2014 & Lady Q Spa International & 555 orang \\
& andSkin Care Medan & \\
\hline
\end{tabular}

Sumber: http://medan.infoisinfo.co.id/cari/perawatan-kulit, 2016

Persaingan yang selalu muncul mendorong timbulnya pemikiran-pemikiran yang baru yang dapat membangun produk atau jasa yang memberikan nilai lebih kepada pelanggan. Industri kecantikan terus menunjukkan daya tariknya, pertumbuhan bisnis ini terus meningkat. Pasar luas menyasar ke pasar menengah, kebawah hingga keatas menawarkan bisnis tersendiri. Salah satu faktor yang membuat berkembangnya industri kecantikan adalah adanya pertumbuhan daya beli masyarakat. Naiknya daya beli masyarakat membuat mereka selalu memperhatikan penampilan. Industri kecantikan di Indonesia sangatlah luas dan menjanjikan, hal ini mendorong berkembangnya berbagai perusahaan kecantikan yang menyebabkan persaingan bisnispun semakin kompetitif. Meningkatnya intensitas persaingan dan jumlah pesaing menuntut perusahaan selalu memperhatikan kebutuhan dan keinginan pelangga serta berusaha memenuhi harapan dengan cara memberikan layanan yang lebih memuaskan.

Tabel Persaingan Antara Clinic Kecantikan di Kota MedanTahun 2014

\begin{tabular}{|c|l|c|}
\hline Tahun & \multicolumn{1}{|c|}{ Nama Skin Care } & $\begin{array}{c}\text { Persentase (\%) } \\
\text { Pengunjung }\end{array}$ \\
\hline 2014 & Natasha Skin Care - Medan & 33 \\
\hline 2014 & Klinik Dermatologi - Medan & 31 \\
\hline 2014 & $\underline{\text { Slimline - Medan }}$ & 31 \\
\hline 2014 & $\underline{\text { Iki Skin Care - Medan }}$ & 31 \\
\hline 2014 & Ricca Skin Care - Medan & 31 \\
\hline
\end{tabular}




\begin{tabular}{|c|c|c|}
\hline 2014 & $\begin{array}{l}\text { Lady Q Spa International \& } \\
\text { Skin Care Medan }\end{array}$ & 31 \\
\hline 2014 & Erha Clinic - Medan & 31 \\
\hline 2014 & Freshly Skin Care - Medan & 28 \\
\hline 2014 & Anny Symphony Skin Care - Medan & 28 \\
\hline 2014 & Skin \& Body Treat $" n^{\prime}$ " "edan & 24 \\
\hline 2014 & $\overline{\text { Chen Dr Skin Care }} 89$ & 24 \\
\hline 2014 & Shine Skin Clinic - ............ & 24 \\
\hline 2014 & Chen Dr Skin Care - Medan & 24 \\
\hline
\end{tabular}

Sumber: http://medan.infoisinfo.co.id/cari/perawatan-kulit, 2015

Berdasarkan data pada tabelPersaingan Antara Clinic Kecantikan di Kota Medan Tahun 2014 diketahui bahwa jumlah persentase pengunjung Clinic Natasha Skin Care Medan memiliki jumlah pengunjung lebih banyak dengan persentase sebesar 33\% pada tahun 2014, sedangkan klinik lainnya berada dibawah Clinic Natasha Skin Care. Perusahaan-perusahaan yang bergerak dibidang industri perawatan kulit tersebut bersaing secara kompetitif untuk mendapatkan pangsa pasar yang banyak, namun dengan banyaknya persaingan maka permasalahan yang dihadapi perusahaan-perusahaan yang bergerak dibidang industri perawatan kulit pun semakin banyak. Selalu saja terdapat masalah yang harus dihadapi oleh perusahaanyang bergerak dibidang industri perawatan kulit seperti komplain yang dilaporkan konsumen ataupun yang paling sering terjadi adalah turunnya jumlah pasien yang datang ke klinik perawatan kulit.

Sebuah perusahaan untuk dapat memenangkan persaingan tidak hanya terletak pada produk yang mereka tawarkan, dimana konsumen juga memilih perusahaan yang sudah mereka anggap mampu untuk memberikan respon yang cepat, menekankan keramahtamahan dapat dipercaya dan ketepatan waktu karyawannya dalam memberikan pelayanan. Selain itu konsumen juga mengharapkan perusahaan mampu memberikan respon cara penyelesaian pengaduan dari pelanggan yang merasa tidak puas dengan barang atau jasa yang dikonsumsi maka terbentuk loyalitas yang merupakan manifestasi dan kelanjutan dari kepuasan konsumen dalam menggunakan fasilitas maupun jasa pelayanan yang diberikan oleh pihak perusahaan, serta untuk tetap menjadi konsumen dari perusahaan tersebut.

\section{LANDASAN TEORI}

Menurut Lupiyoadi (2006:5) pemasaran jasa adalah setiap tindakan yang ditawarkan oleh salah satu pihak kepada pihak lain yang secara prinsip intangible dan tidak menyebabkan perpindahan kepemilikan apapun. Umar (2003:76) pemasaran jasa adalah pemasaran yang bersifat intangible dan immaterial dan dilakukan pada saat konsumen berhadapan dengan produsen. Dari definisi tersebut pemasaran jasa adalah suatu tindakan yang ditawarkan pihak produsen kepada konsumen, dalam arti jasa yang diberikan tidak dapat dilihat, dirasa, didengar atau diraba sebelum dikonsumsi.

Jasa sering dipandang sebagai suatu fenomena yang rumit, kata jasa (service) itu sendiri mempunyai banyak arti, mulai dari pelayanan pribadi (personal service) sampai jasa sebagai suatu produk. Lupiyoadi (2006:6) mendefinisikan jasa adalah Setiap tindakan atau kegiatan yang dapat ditawarkan oleh satu pihak kepada pihak lain, pada dasarnya tidak berwujud dan tidak mengakibatkan kepemilikan apapun. Produksi jasa bisa berkaitan dengan produk fisik atau sebaliknya. Dari pengertian tersebut jasa merupakan aspek interaksi antara pihak konsumen dan pihak produsen (jasa), meskipun pihak-pihak yang terlibat tidak selalu 
menyadari. Jasa bukan suatu barang, melainkan suatu proses atau aktivitas yang tidak berwujud.

Menurut Tjiptono (2005:121) kualitas layanan sebagai ukuran seberapa baik tingkat layanan yang diberikan mampu sesuai dengan harapan pelanggan. Faktor utama yang mempengaruhi kualitas pelayanan, yaitu: jasa yang diharapkan dan jasa yang dirasakan/dipersepsikan. Apabila jasa yang dirasakan sesuai dengan jasa yang diharapk yang diharapkan, maka kualitas jasa diper: 90 sebaliknya, apabila jasa yang dipersepsikan agai kualitas ideal. Demiki; libandingkan jasa yang dihaıмгмu, maka kualitas jasa dipersepsikan negatif/buruk. Maka naik tidaknya kualitas pelayanan tergantung pada kemampuan penyedia jasa dalam memenuhi harapan pelanggannya secara konsisten.

Kotler dkk (2009:146) menyatakan bahwa kepuasan adalah tingkat perasaan seseorang setelah membandingkan kinerja produk atau hasil yang ia rasakan dengan harapannya. Tingkat kepuasan merupakan fungsi perbedaan antara kinerja yang dirasakan (perceived performance) dan harapan (expectation). Jika kinerja dibawah harapan, pelanggan akan tidak puas. Jika kinerja sesuai dengan harapan, pelanggan akan sangat puas, senang atau bahagia.Tujuan akhir dari semua perusahaan adalah apabila memiliki pelanggan yang loyal. Namun kebanyakan perusahaan tidak mengetahui bahwa loyalitas konsumen dapat dibentuk melalui beberapa tahapan. Mulai dari mencapai calon pelanggan potensial sampai dengan advocate customers yang akan membawa keuntungan bagi perusahaan. Utami (2006:88) menyatakan bahwa loyalitas lebih ditunjukkan pada suatu perilaku yang ditunjukkan dengan pembelian rutin, didasarkan pada pengambilan keputusan.

Menurut Kotler (2001:28) jasa merupakan produk yang tidak terwujub (intangible), hal ini dapat dinikmati oleh pelanggan adalah manfaat (benefit), yang memberikan kepuasan kepada pelanggan.Terciptanya kepuasan pelanggan dapat memberikan beberapa manfaat, diantaranya hubungan antara perusahaan dan pelanggan menjadi harmonis memberikan dasar yang baik bagi pembelian ulang dan terciptanya loyalitas pelanggan, dan membentuk suatu rekomendasi dari mulut ke mulut (word of mounth) yang menguntungkan perusahaan (Tjiptono, 2005:45).

Menurut Tjiptono (2005:121) kualitas layanan sebagai ukuran seberapa baik tingkat layanan yang diberikan mampu sesuai dengan harapan pelanggan. Faktor utama yang mempengaruhi kualitas pelayanan, yaitu jasa yang diharapkan dan jasa yang dirasakan/dipersepsikan. Apabila jasa yang dirasakan sesuai yang diharapkan, maka kualitas pelayanan tersebut akan dipersepsikan baik atau positif.

\section{METODE PENELITIAN}

Jenis Penelitian

Jenis penelitian ini berupa deskriptif kuantitatif. Menurut Sugiyono (2010:62) metode penelitian merupakan cara ilmiah untuk mendapatkan data, baik data yang bersifat data sekunder maupun data primer, dengan tujuan dan kegunaan tertentu. Tujuan dari metode deskriptif kuantitatif ini yaitu membuat suatu uraian yang sistematis mengenai fakta-fakta dan sifat-sifat dari objek yang diteliti kemudian menggabungkan hubungan antar variabel yang terlibat di dalamnya. Peneltian ini juga menekankan analisisnya pada data-data numerik (angka) yang diolah dengan menggunakan metode statistika.Adapun sifatdari penelitian ini adalah penelitian yang bersifat menjelaskan (deskriptif explanatory). Menurut Sugiyono (2010) bahwa "Penelitian deskriptif explanatory adalah penelitian yang bermaksud menjelaskan kedudukan variabel-variabel yang diteliti serta pengaruh antara satu variabel dengan variabel yang lain".

\section{Tempat dan Waktu Penelitian}


Penelitian ini dilakukan di Clinic Natasha Skin Care Jalan Gajah Mada No.7 Medan. Pelaksanaan penelitian dimulai dari bulan Januari 2016 sampai dengan bulan April 2016.

\section{Populasi dan Sampel Populasi}

Populasi menurut Sugiyono (201 atas objek/subjek yang mempunyai $\mathrm{k}$

si adalah wilayah generalisasi yan arakteristik tertentu yang ditetapl

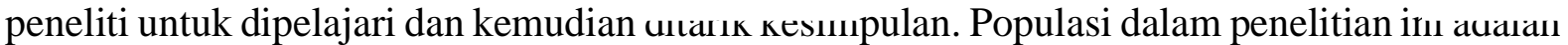
pelangganClinic Natasha Skin Care Medanyang telah melakukan perawatan bejenis kelamin wanita berjumlah 1080 orang.

\section{Sampel}

Sampel menurut Sugiyono (2010:86) yaitu bagian dari jumlah dan karakteristik yang dimiliki oleh populasi tersebut. Besarnya jumlah sampel yang harus diambil dari populasi dalam suatu kegiatan penelitian sangat tergantung dari keadaan populasi itu sendiri, maka jumlah sampel semakin sedikit, begitu juga sebaliknya. Penetapan ukuran sampel dari populasi dapatdigunakan dengan rumus Slovin, dimana penetapan sampel mempertimbangkan batas ketelitian yang dapat mempengaruhi kesalahan pengambilan sampel populasi (Sugiyono 2010:86). Rumus Slovin tersebut adalah sebagai berikut:

$$
\begin{aligned}
n & =\frac{N}{1+N e^{2}} \\
& =\frac{1080}{1+1080(0.1)^{2}} \\
n & =92 \text { orang }
\end{aligned}
$$

Keterangan $\quad \mathrm{n}=$ Jumlah Sampel

$\mathrm{N}=$ Ukuran Populasi

$\mathrm{e}=$ Standart error $=10 \%$

Berdasarkan hasil perhitungan tersebut, maka jumlah sampel yang akandigunakan untuk penelitian inisebanyak92 orang. Pengambilan sampel dilakukan dengan pelanggan yang melakukan perawatan kecantikan diClinic Natasha Skin Care Medan.

\section{Uji Validitas dan Reliabilitas}

\section{Uji Validitas}

Uji validitas adalahindeks yang menunjukkan suatu alat pengukur dengan mengukur apa yang ingin diukur. Kriteria dalam menentukan validitas suatu kuesioner adalah sebagai berikut:Jika $r$ hitung $\geq \mathrm{r}$ tabel maka pernyataan dinyatakan valid danJika $\mathrm{r}$ hitung $\leq \mathrm{r}$ tabel maka pernyataan dinyatakan tidak valid.Penulis melakukan uji coba instrumen di Clinic Natasha Skin Care Jalan Gajah Mada No.7 Medan yang berisi 26 pertanyaan kepada 30 responden yang melakukan perawatan kecantikan.Hasil uji validitas tahap 1 dalam penelitian ini adalah :

\section{Tabel Hasil Pengujian Validitas Tahap 1}




\section{Item-Total Statistics}

\begin{tabular}{|c|c|c|c|c|}
\hline & $\begin{array}{l}\text { Scale Mean if } \\
\text { Item Deleted }\end{array}$ & $\begin{array}{c}\text { Scale Variance if } \\
\text { Item Deleted }\end{array}$ & $\begin{array}{c}\text { Corrected Item- } \\
\text { Total } \\
\text { Correlation }\end{array}$ & $\begin{array}{c}\text { Cronbach's } \\
\text { Alpha if Item } \\
\text { Deleted }\end{array}$ \\
\hline $\mathrm{P} 1$ & 120.03 & 226.240 & .476 & .924 \\
\hline $\mathrm{P} 2$ & 120.33 & 225.333 & .555 & .924 \\
\hline P3 & 120.13 & 223.016 & .514 & .924 \\
\hline $\mathrm{P} 4$ & 120.57 & 212.047 & .823 & .919 \\
\hline P5 & 120.33 & ר? & .534 & .924 \\
\hline P6 & 120.27 & & -.038 & .931 \\
\hline P7 & 120.20 & 223.545 & .509 & .924 \\
\hline P8 & 120.63 & 212.723 & .756 & .920 \\
\hline P9 & 120.40 & 216.248 & .670 & .922 \\
\hline $\mathrm{P} 10$ & 120.43 & 214.737 & .739 & .921 \\
\hline P11 & 120.17 & 222.489 & .574 & .923 \\
\hline P12 & 120.37 & 230.861 & .289 & .926 \\
\hline P13 & 120.80 & 230.510 & .177 & .929 \\
\hline P14 & 120.27 & 224.616 & .553 & .924 \\
\hline P15 & 120.23 & 231.633 & .286 & .926 \\
\hline P16 & Lanjutar & Hasil Pengujian Val & iditas Tahap 1 & .923 \\
\hline $\mathrm{P} 17$ & 120.07 & 228.892 & .290 & .927 \\
\hline P18 & 120.00 & 225.241 & .613 & .923 \\
\hline P19 & 120.47 & 217.154 & .696 & .921 \\
\hline $\mathrm{P} 20$ & 120.77 & 223.978 & .619 & .923 \\
\hline $\mathrm{P} 21$ & 120.50 & 221.845 & .488 & .924 \\
\hline $\mathrm{P} 22$ & 120.60 & 217.972 & .655 & .922 \\
\hline $\mathrm{P} 23$ & 120.60 & 225.628 & .371 & .926 \\
\hline P24 & 120.47 & 217.844 & .554 & .923 \\
\hline $\mathrm{P} 25$ & 120.63 & 222.999 & .462 & .925 \\
\hline P26 & 120.33 & 218.299 & .537 & .924 \\
\hline $\mathrm{P} 27$ & 120.07 & 221.651 & .530 & .924 \\
\hline P28 & 120.23 & 214.737 & .668 & .922 \\
\hline P29 & 120.33 & 218.299 & .648 & .922 \\
\hline P30 & 120.13 & 223.913 & .573 & .923 \\
\hline P31 & 120.47 & 222.533 & .404 & .926 \\
\hline
\end{tabular}

\section{Sumber: Hasil Penelitian, 2016}

Berdasarkan Tabel Hasil Pengujian Validitas Tahap 1 diperoleh hasil dari pengujian Berdasarkan Tabel Hasil Pengujian Validitas Tahap 1diperoleh hasil dari pengujian memiliki nilai yang lebih besar dari 0,361 kecuali pada pertanyaan P6, P12, P13, P15, P17, lebih kecil dari 0,361 ini berarti bahwa harus dilakukan pengujian validitas tahap 2 dengan cara menguji 
kembali setiap butir soal yang valid setelah butir pertanyaan P6,P12, P13, P15, P17 dibuang. Hasil uji validitas tahap 2 dapat dilihat pada tabel berikut:

Tabel Hasil Pengujian Validitas Tahap 2 Item-Total Statistics

\begin{tabular}{|c|c|c|c|c|}
\hline & $\begin{array}{l}\text { Scale Mean if } \\
\text { Item Deleted }\end{array}$ & $\begin{array}{l}\text { Scale Variance if } \\
\text { Item Deleted }\end{array}$ & $\begin{array}{c}\text { Corrected Item- } \\
\text { Total } \\
\text { Correlation }\end{array}$ & $\begin{array}{c}\text { Cronbach's } \\
\text { Alpha if Item } \\
\text { Deleted }\end{array}$ \\
\hline P1 & 99.93 & 200.547 & .465 & .934 \\
\hline $\mathrm{P} 2$ & 100.23 & 198.944 & .584 & .933 \\
\hline P3 & 100.03 & 93 & .520 & .933 \\
\hline P4 & 100.47 & & .806 & .929 \\
\hline P5 & 100.23 & 196.047 & .520 & .933 \\
\hline P7 & 100.10 & 197.610 & .516 & .933 \\
\hline P8 & 100.53 & 188.120 & .737 & .930 \\
\hline P9 & 100.30 & 191.252 & .657 & .931 \\
\hline P10 & 100.33 & 189.264 & .748 & .930 \\
\hline P11 & 100.07 & 196.616 & .582 & .932 \\
\hline P14 & 100.17 & 198.695 & .558 & .933 \\
\hline P16 & 100.07 & 196.478 & .626 & .932 \\
\hline P18 & 99.90 & 199.334 & .616 & .932 \\
\hline P19 & \multicolumn{3}{|c|}{ Lanjutan Hasil Pengujian Validitas Tahap 2} & .930 \\
\hline $\mathrm{P} 20$ & 100.67 & 198.230 & .617 & .932 \\
\hline $\mathrm{P} 21$ & 100.40 & 196.800 & .464 & .934 \\
\hline $\mathrm{P} 22$ & 100.50 & 192.190 & .669 & .931 \\
\hline $\mathrm{P} 23$ & 100.50 & 199.707 & .372 & .935 \\
\hline P24 & 100.37 & 191.895 & .571 & .933 \\
\hline $\mathrm{P} 25$ & 100.53 & 196.947 & .474 & .934 \\
\hline $\mathrm{P} 26$ & 100.23 & 192.737 & .540 & .933 \\
\hline P27 & 99.97 & 196.585 & .506 & .933 \\
\hline $\mathrm{P} 28$ & 100.13 & 189.430 & .670 & .931 \\
\hline $\mathrm{P} 29$ & 100.23 & 192.944 & .644 & .931 \\
\hline P30 & 100.03 & 197.689 & .596 & .932 \\
\hline P31 & 100.37 & 197.275 & .389 & .936 \\
\hline
\end{tabular}

\section{Sumber: Hasil Penelitian, 2016}

Berdasarkan tabel Hasil Pengujian Validitas Tahap 2diperoleh bahwa hasil dari pengujian memiliki nilai yang lebih besar dari 0.361. Disimpulkan bahwa seluruh pertanyaan adalah valid dan dapat digunakan dalam penelitian. 


\section{Uji Reliabilitas}

Uji reliabilitas adalah indeks yang menunjukkan suatu alat pengukur dapat dipercaya atau dapat diandalkan. Uji reliabilitas digunakan untuk melihat apakah alat ukur yang digunakan menunjukkan konsistensi didalam mengukur gejala yang sama. Pernyataan yang telah dinyatakan valid dalam uji validitas, maka akan ditentukan reliabilitasnya dengan kriteria sebagai berikut:Jika $\mathrm{r} \alpha$ (alpha) positif atau $\geq$ dari $\mathrm{r}$ tabel maka pernyataan reliable dan Jika $\mathrm{r} \alpha$ (alpha) negatif atau $\leq$ dari $\mathrm{r}$ tabel maka pernyataan tidak reliabel.Suatu konstruk atau variabel dikatakan reliable jika memberikan nilai Cronbach Alpha> 0.8, berdasarkan hasil pengolahan data untuk uji reliabilitas dapat dilihat pada tabel berikut:

Tabel Hasil Uji Reliabilitas

\begin{tabular}{|c|c|c|}
\hline Relia 94 & & \\
\hline Cronbach's & : & Nof Items \\
\hline .935 & & 26 \\
\hline
\end{tabular}

\section{Sumber: Hasil Penelitian, 2016}

Tabel Hasil Uji Reliabilitasmenunjukkan bahwa 26 pertanyaan dengan koefisien alpha (Cronbach's Alpha) adalah 0,935. Hal ini berarti 0,935 >0.80, sehingga dapat dinyatakan bahwa kuesioner tersebut telah reliabel dan layak disebarkan kepada responden untuk digunakan sebagai instrumen dalam penelitian ini.

\section{HASIL PENELITIAN}

\section{Uji Normalitas}

Uji normalitas bertujuan untuk mengetahui apakah distribusi sebuah data mengikuti atau mendekati distribusi normal Situmorang dan Lutfi (2014:175).Hasil pengujian normalitas dapat dilihat pada Gambar Grafik Normal P-Plot of Regression Standardized Residual. Dengan melihat pola titik-titik plot dari keduanya berbentuk linear (dapat didekati oleh garis lurus), yang merupakan sebaran data (dalam hal ini residual)menyebar normal.Berikut ini merupakan hasil Normal P-Plot of Regression Standardized Residual.

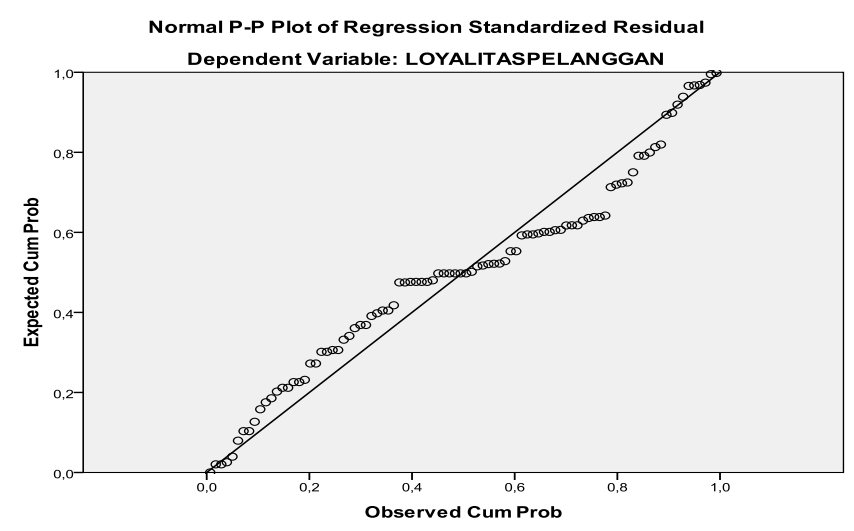

Gambar Grafik P-Plot Uji Normalitas

Sumber: Hasil Penelitian, 2016 
Untuk memastikan apakah data di sepanjang garis diagonal berdistribusi normal maka dilakukan uji Kolmogorov-Smirnov Test. Berikut ini merupakan hasil uji Kolmogorov-Smirnov Test:

Tabel Hasil Uji Kolmogorov-Smirnov

One-Sample Kolmogorov-Smirnov Test

\begin{tabular}{|c|c|c|}
\hline & & $\begin{array}{c}\text { Unstandardized } \\
\text { Residual }\end{array}$ \\
\hline $\mathrm{N}$ & & 92 \\
\hline Normal & Mean & ,0000000 \\
\hline Parametersa, $b$ & Std. Deviation & 3,76474749 \\
\hline Most Extreme & Absolute &, 139 \\
\hline Differences & Positive & ,139 \\
\hline & Negative &,- 105 \\
\hline Kolmogorov- $\mathrm{S}$, & $v Z$ & 1,334 \\
\hline Asymp. Sig. (2- & d) & ,057 \\
\hline
\end{tabular}

\section{Sumber: Hasil Penelitian 2016}

Berdasarkan Tabel Hasil Uji Kolmogorov-Smirnov diketahui bahwa Asymp. Sig. (2 tailed) adalah 0,057 dan di atas nilai signifikan $(0,01)$, dengan demikian variabel residual berdistribusi normal. Nilai Kolmogorov-Smirnov Z lebih kecil dari 1,96 berarti tidak ada perbedaan antara distribusi teoritik dan distribusi empirik atau dengan kata lain data dikatakan normal.

\section{Uji Heteroskedostisitas}

Pengujian heteroskedastisitas ini digunakan dalam model regresi untuk melihat terjadi ketidaksamaan varians dariresidual satu ke pengamatan yang lain.Jika varians berbeda disebutheteroskedastisitas.Pendekatan yang digunakan untuk melakukan uji heteroskedostisitas dalam penelitian ini adalah dengan gambarScatterplot Model dan Uji Glejser.Berikut ini grafik heteroskedastisitasScatterplot Model:

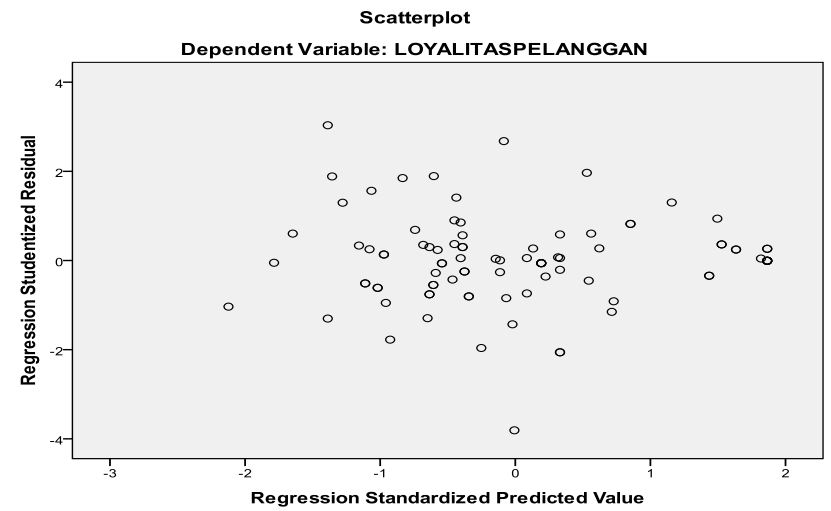

Gambar Grafik Heteroskedastisitas

Sumber: Hasil Penelitian, 2016 
Melalui analisis grafik, suatu model regresi dianggap tidak terjadi heteroskedastisitas jika titik-titik menyebar secara acak dan tidak membentuk suatu pola tertentu yang jelas serta tersebar di atas maupun dibawah angka nol pada sumbu Y. Maka pada gambar Grafik Heteroskedastisitasmenunjukkan bahwa titik-titik menyebar secara acak maka tidak terjadi heteroskedastisitas.

Tabel Hasil Uji Glejser Coefficients

\begin{tabular}{|c|c|c|c|c|c|}
\hline \multirow[t]{2}{*}{ Model } & \multicolumn{2}{|c|}{$\begin{array}{c}\text { Unstandardized } \\
\text { Coefficients } \\
\end{array}$} & \multirow{2}{*}{$\begin{array}{c}\begin{array}{c}\text { Standardized } \\
\text { Coefficients }\end{array} \\
\text { Beta }\end{array}$} & \multirow[b]{2}{*}{$\mathrm{t}$} & \multirow[b]{2}{*}{ Sig. } \\
\hline & $\mathrm{B}$ & Std. Error & & & \\
\hline $1 \quad$ (Constant) & 9,521 & 2,572 & & 3,702 & $\overline{, 000}$ \\
\hline Kualitas Pelayanan &,- 080 &, 059 &,- 160 & $-1,360$ & 177 \\
\hline Kepuasan Pelanggan &,- 151 &, 110 &,- 161 & $-1,367$ & ,175 \\
\hline
\end{tabular}

a. Dependent Variable: ABSOLUT

\section{Sumber: Hasil Penelitian, 2016}

Pada TabelHasil Uji Glejser dapat dilihat bahwavariabel bebas $\mathrm{X}(0,177), \mathrm{Y}_{1}(0,175)$ dengan signifikansinya di atas tingkat kepercayaan $1 \%$, maka dapat dinyatakan bahwa model regresi tidak mengarah adanya heteroskedastisitas.

\section{Uji Multikolinearitas}

Uji multikolinearitas bertujuan untuk menguji apakah dalam model regresi ditemukan adanya korelasi antar variabel bebas. Dalam model regresi yang baik seharusnya tidak saling korelasi diantara variabel bebas (tidak terjadi multikolinearitas).Untuk mendeteksi ada atau tidaknya multikolinieritas dapat dilakukan dengan melihat toleransi variabel dan Variance Inflation Factor (VIF) dengan membandingkan sebagai berikut:VIF >10 maka diduga mempunyai persoalan multikolinieritas, VIF $<10$ maka tidak terdapat multikolinieritas, Tolerane $<0,1$ maka diduga mempunyai persoalan multikolinieritas dan Tolerance $>0,1$ maka tidak terdapat multikolinieritas. Hasil pengolahan dari Uji Multikolinearitasdapat dilihat pada tabel berikut :

\section{Tabel Hasil Uji Multikolinearitas}




\begin{tabular}{|l|r|r|}
\multicolumn{2}{c|}{ Coefficients $^{\mathbf{a}}$} \\
\cline { 2 - 3 } & \multicolumn{2}{|c|}{ Collinearity Statistics } \\
\cline { 2 - 3 } & Tolerance & \multicolumn{2}{|c|}{ VIF } \\
\hline (Constant) & & \\
Kualitas Pelayanan & $\mathbf{7 5 0}$ & $\mathbf{1 , 3 3 3}$ \\
Kepuasan Pelanggan & $\mathbf{7 5 0}$ & $\mathbf{1 , 3 3 3}$ \\
\hline
\end{tabular}

a. Dependent Variable: Loyalitas Pelanggan

\section{Sumber: Hasil Penelitian, 2016}

Dari TabelHasil Uji Multikolinearitas memperlihatkan bahwa nilai VIFKualitas Pelayanan $(\mathrm{X})$ sebesar $(1,333)$ dan Kepuasan Pelanggan $\left(\mathrm{Y}_{1}\right)$ sebesar $(1,333)<10$ maka tidak terjadi Multikolinieritas.Dari nilai ToleranceKualitas Pelayanan (X) sebesar $(0,750)$ danKepuasan Pelanggan $\left(\mathrm{Y}_{1}\right)$ sebesar $(0,750)$, > 0,1 maka tidak terjadi multikolinieritas.

\section{Hasil Analisis Regresi Linear Berganda}

Analisis regresilinear berganda berfungsi untuk mengetahui pengaruh variabel bebas (independent variable) yaitu kualitas pelayanan $(\mathrm{X})$, terhadap variabel terikat (dependent variable) yaitu kepuasan pelanggan $\left(\mathrm{Y}_{1}\right)$ dan loyalitas pelanggan $\left(\mathrm{Y}_{2}\right)$. Hasil Analisis Regresi Linear Bergandadengan program software SPSS (statistic product and service solution)adalah sebagai berikut :

\section{Tabel Analisis Regresi Linear Berganda}

Coefficients $^{\text {a }}$

\begin{tabular}{|l|r|r|r|r|r|}
\hline \multirow{2}{*}{ Model } & \multicolumn{2}{|c|}{$\begin{array}{c}\text { Unstandardized } \\
\text { Coefficients }\end{array}$} & $\begin{array}{c}\text { Standardized } \\
\text { Coefficients }\end{array}$ & & \multirow{2}{*}{} \\
\cline { 2 - 5 } & \multicolumn{1}{|c|}{$\mathbf{B}$} & \multicolumn{1}{c|}{$\begin{array}{c}\text { Std. } \\
\text { Error }\end{array}$} & Beta & \multicolumn{1}{c|}{ t } & Sig. \\
\hline 1 (Constant) & $\mathbf{4 , 3 2 8}$ & 3,673 & & 1,178 &, 242 \\
Kualitas Pelayanan & $\mathbf{, 1 8 8}$ &, 084 &, 185 & 2,222 &, 029 \\
Kepuasan Pelanggan & $\mathbf{1 , 1 8 3}$ &, 158 &, 624 & 7,498 &, 000 \\
\hline
\end{tabular}

a. Dependent Variable: Loyalitas Pelanggan

Dari Tabel Analisis Regresi Linear Berganda diketahui kolom Unstandardized Coefficients pada bagian b diperoleh nilai b1 kualitas pelayanan sebesar 0,188 , nilai b2 kepuasan pelanggan 1,183, dan nilai konstanta (a) adalah 4,328 maka diperoleh persamaan regresi berganda sebagi berikut:

$$
\mathrm{Y}=\mathbf{4 , 3 2 8}+\mathbf{0 . 1 8 8}+\mathbf{1 , 1 8 3}+\mathrm{e}
$$

Penjelasan persamaan regresi berganda tersebut adalah : Nilai konstanta (a) sebesar 4,328artinya jika Kualitas Pelayanandan Kepuasan Pelanggan nilainya adalah 0 maka Loyalitas Pelangganakan meningkat sebesar 4,380di Clinic Natasha Skin CareMedan. Nilai koefisien regresi Kualitas Pelayanan $\left(b_{1}\right)$ bernilai positif yaitu 0,188 artinya bahwa setiap terjadi peningkatan Kualitas Pelayanansebesar 0,188maka Loyalitas Pelanggandi Clinic Natasha Skin CareMedanjuga akan meningkat sebesar 0,188dengan asumsi variabel independen lain tetap.Nilai koefisien regresi Kepuasan Pelanggan $\left(b_{2}\right)$ bernilai positif yaitu 1,183artinya bahwa setiap terjadi peningkatan Kepuasan Pelanggan sebesar 1,183maka Loyalitas Pelanggandi 
Clinic Natasha Skin CareMedanjuga akan meningkatsebesar 1,183dengan asumsi variabel independen lain tetap.

Koefisien Determinasi $\left(\mathbf{R}^{2}\right)$.

Uji Koefisien Determinan $\left(\mathrm{R}^{2}\right)$ digunakan untuk mengukur seberapa besar kontribusi variabel bebas terhadap variabel terikat. Jika koefisien Determinan $\left(\mathrm{R}^{2}\right)$ semakin besar dan mendekati satu) menunjukkan semakin baik kemampuan menerangkan $\mathrm{Y}$ dimana $\mathrm{Y}$ dimana $0<\mathrm{R}^{2}<1$. Sebaliknya, jika $\mathrm{R}^{2}$ semakin kecil (mendekati nol), maka akan dapat dikatakan bahwa pengaruh variabel bebas $(\mathrm{X})$ adalah kecil terhadap variabel terikat $(\mathrm{Y})$. Hal ini berarti model yang digunakan tidak kuat untuk menerangkan pengaruh variabel bebas yang diteliti terhadap variabel terikat. Hasil pengolahan dari analisis regresi linier berganda untuk koefisien determinasi $\left(\mathrm{R}^{2}\right)$ dapat dilihat pada tabel berikut ini:

Tabel Koefisien Determinasi $\left(\mathbf{R}^{2}\right)$

\begin{tabular}{|c|c|c|c|c|}
\hline Model & $\mathrm{R}$ & R Square & $\begin{array}{c}\text { Adjusted } \\
\text { R Square }\end{array}$ & $\begin{array}{c}\text { Std. Error of } \\
\text { the Estimate }\end{array}$ \\
\hline 1 &, $734 \mathrm{a}$ & $\mathbf{, 5 3 8}$ &, 528 & 3,807 \\
\hline
\end{tabular}

a. Predictors: Constant), Kepuasan Pelanggan, Kualitas Pelayanan

Dependent Variabel: Loyalitas Pelanggan

Sumber:Hasil Penelitian, 2016

Dari tabel Koefisien Determinasi $\left(\mathrm{R}^{2}\right)$ nilaiR Square sebesar 0.538 bearti $53.8 \%$ faktorfaktor Loyalitas Pelanggan dapat dijelaskan oleh hubungan Kualitas pelayanan dan kepuasan pelanggan. Sedangkan sisanya 43,8\% dapat dijelaskan oleh faktor-faktor lain yang tidak diteliti dalam penelitian ini.

\section{Uji Signifikansi Parsial (Uji t)}

Pengujian ini dilakukan untuk mengetahui seberapa besar pengaruh variabel bebas yaitu Kualitas Pelayanan(X)secara parsial terhadap variabel terikatKepuasan Pelanggan( $\left.\mathrm{Y}_{1}\right)$ dan Loyalitas Pelanggan( $\left.\mathrm{Y}_{2}\right)$.Hasil pengolahan dari Uji t dapat dilihat pada tabel berikut:

Tabel Hasil Uji Signifikan Parsial (Uji t) Coefficients $^{\text {a }}$

\begin{tabular}{|ll|r|r|r|r|r|}
\hline \multirow{2}{*}{ Model } & \multicolumn{2}{|c|}{$\begin{array}{c}\text { Unstandardized } \\
\text { Coefficients }\end{array}$} & $\begin{array}{c}\text { Standardized } \\
\text { Coefficients }\end{array}$ & & \\
\cline { 2 - 4 } & \multicolumn{1}{|c|}{ B } & \multicolumn{1}{c|}{$\begin{array}{c}\text { Std. } \\
\text { Error }\end{array}$} & Beta & \multicolumn{1}{c|}{ T } & \multirow{2}{*}{ Sig. } \\
\hline \multirow{2}{*}{1} & (Constant) & 4,328 & 3,673 & & $\mathbf{1 , 1 7 8}$ &, 242 \\
& Kualitas Pelayanan &, 188 &, 084 &, 185 & $\mathbf{2 , 2 2 2}$ &, 029 \\
& Kepuasan Pelanggan & 1,183 &, 158 &, 624 & $\mathbf{7 , 4 9 8}$ &, 000 \\
\hline
\end{tabular}

a. Dependent Variable: Loyalitas Pelanggan

\section{Sumber: Hasil Penelitian, 2016}

Terlihat pada kolomCoefficientsvariabel kualitas pelayanan (X) mempunyai nilai $\mathrm{t}_{\text {hitung }}$ $(2,222)<t_{\text {tabel }}(2,682)$ yang berarti Ho diterima dan Ha ditolak. Sedangkan pada nilai signifikan lebih besar dari nilai probabilitas 0,01 atau nilai signifikan 0,029>0,01. Dengan demikian dapat disimpulkan variabel kualitas pelayanan (X) tidak berpengaruh dan tidak signifikan terhadap loyalitas pelanggan pada $\alpha=1 \%$.Pada kolom Coefficients variabel Kepuasan 
Pelanggan $\left(\mathrm{Y}_{1}\right) \mathrm{t}_{\text {hitung }}(7,498)>\mathrm{t}_{\text {tabel }}(2,682)$ yang berarti Ho ditolak dan Ha diterima. Sedangkan nilai signifikan lebih kecil dari nilai probabilitas 0,01 atau nilai signifikan $0,029<0,01$. Dengan demikian dapat disimpulkan variabel Kepuasan Pelanggan $\left(\mathrm{Y}_{1}\right)$ berpengaruh positif dan signifikan terhadap Loyalitas Pelanggan $\left(\mathrm{Y}_{2}\right)$ pada $\alpha=1 \%$. Artinya jika ditingkatkan variabel kualitas pelayanan sebesar satu satuan (unit) maka loyalitas Pelanggan akan meningkat sebesar 1,183satuan (unit).

\section{b. Uji Signifikansi Simultan (Uji F)}

Uji F bertujuan untuk mengetahui pengaruh secara serempak ataubersama-sama variabel bebas(Kualitas Pelayanan)terhadapvariabel terikat (Kepuasan Pelanggan dan Loyalitas Pelanggan). Uji Signifikansi Simultan(Uji F) dilakukan dengan membandingkan $F_{\text {hitung }}$ dan $\mathrm{F}_{\text {tabel. }}$ Kriteria pengambilan keputusan adalah $: \mathrm{H}_{0}$ diterima jika $\mathrm{F}_{\text {hitung }}<\mathrm{F}_{\text {tabel }}$ pada $\alpha=1 \%$.Ha diterimajika $F_{\text {hitung }}>F_{\text {tabel }}$ pada $\alpha=1 \%$.Nilai $F_{\text {hitung diperoleh dengan menggunakan software }}$ SPSS, kemudian akan dibandingkan dengan nilai $\mathrm{F}_{\text {tabel }}$ pada tingkat $\alpha=1 \%$ Dengan derajat pembilang: $\mathrm{k}-1=3-1=2$. Derajat penyebut: $\mathrm{n}-\mathrm{k}-1=92-2-1=89$. Hasil pengolahan SPSS untuk Uji F adalah sebagai berikut:

Tabel Hasil Uji Simultan (Uji F)

Hasil Uji F

ANOVA ${ }^{b}$

\begin{tabular}{|c|c|c|c|c|c|c|}
\hline & Model & $\begin{array}{c}\text { Sum of } \\
\text { Squares }\end{array}$ & Df & $\begin{array}{c}\text { Mean } \\
\text { Square }\end{array}$ & $\mathbf{F}$ & Sig. \\
\hline \multirow[t]{3}{*}{1} & Regression & 1502,956 & 2 & \multirow{3}{*}{$\begin{array}{r}751,478 \\
14,492\end{array}$} & \multirow[t]{3}{*}{51,855} & \multirow[t]{3}{*}{, $000 \mathrm{a}$} \\
\hline & Residual & 1289,772 & 89 & & & \\
\hline & Total & 2792,728 & 91 & & & \\
\hline
\end{tabular}

a. Predictors: (Constant), Kepuasan Pelanggan, Kualitas Pelayanan

b. Dependent Variable: Loyalitas Pelanggan

\section{Sumber: Hasil Penelitian, 2016}

Nilai $F_{\text {hitung }}$ sebesar 51,855sedangkan nilai $F_{\text {tabel }}$ pada tingkat kepercayaan $99 \%(\alpha=0,01)$ adalah 3,098. Ini berarti $F_{\text {hitung }}$ 51,855 $>F_{\text {tabel }} 3$,098yaitu Ha diterima dan Ho ditolak. Untuk tingkat signifikansinya $0,000<0,01$, menunjukkan bahwa variabelKualitas Pelayanansecara bersama-sama (secara serempak) berpengaruh positif dan signifikan terhadap Kepuasan Pelanggandan Loyalitas Pelanggandi Clinic Natasha Skin CareMedan

\section{KESIMPULAN}

1. Hasil Penelitian berdasarkan uji t menunjukkan Kualitas Pelayanan berpengaruh secara positif dan siginifikan terhadap Kepuasan Pelanggan, Sedangkan Kepuasan Pelanggan tidakberpengaruh secara positif dan signifikan terhadap Loyalitas Pelanggan 
ClinicNatashaSkin Care Medan yang disebabkan adanya pelanggan yang kurang puas dengan jasa yang diberikan Clinic NatashaSkin Care Medan

2. Hasil penelitian berdasarkan uji $F$ menunjukkan bahwa variabel Kualitas Pelayananbersama-sama (secara serempak) berpengaruh positif dan signifikan terhadap Kepuasan Pelanggan dan Loyalitas Pelanggan padaClinicNatashaSkin Care Medan.

\section{REFERENSI}

\section{Buku:}

Husein, Umar, 2003. Metodologi Penelitian Untuk Skripsi dan Tesis Bisnis.Penerbit Gramedia Pustaka, Jakarta.

Kotler, Philip dan Gary Armstrong, 2001. Prinsip-prinsip Pemasaran, Jilid 2 Edisi Kedelapan, Penerbit Erlangga, Jakarta.

Kotler, Philip dan Keller, Kevin Lane, 2009. Manajemen Pemasaran, Edisi Ketiga Belas, Jilid Satu, PenerbitErlangga, Jakarta.

Kotler, Philip dan Keller, Kevin Lane, 2009. Manajemen Pemasaran, Edisi Ketiga Belas, Jilid Dua, PenerbitErlangga, Jakarta.

Lupiyoadi,Hamdani, 2006. Manajemen Pemasaran Jasa. Edisi Kedua,PenerbitSalemba Empat, Jakarta

Situmorang dan Lufti, 2014. Analisis Data untuk Riset Manajemen dan Bisnis, USU Press, Medan.

Sugiyono, 2010. Metode Penelitian Kuantitatif dan kualitatif. PenerbitAlfabeta, Bandung. Tjiptono, Fandy, 2005, Pemasaran JasaEdisi Pertama, Penerbit Bayumedia Publishing, Malang Umar, Husein, 2003. Metode Penelitian Untuk Skripsi dan Tesis dan Bisnis. PenerbitGramedia Pustaka, Jakarta

Utami, Widya, Cristina, 2006, Manajemen Ritel, Penerbit Salemba Empat, Jakarta 
Internet:

Potensi Pasar dan Kecantikan (2014). Dalam http://www.marketing.co.id/potensi-pasarproduk-kecantikan-di-indonesia. Diunduh pada tanggal 14 Februari 2016 pukul 20.00 WIB 